\title{
Implementation of Government Regulation No. 2/2003 and Perkap No. 14/2011 on Code Enforcement in Polres Purworejo
}

\section{Purwanto $^{1}$}

Abstract. The purpose of this study was to determine the effectiveness of the law in PP 2/2003 of Police Regulation No.14 of 2011 of Police Purworejo. In accordance with the existing problems, then it can be taken a result that the implementation of the Police Regulation in police office of Senapelan not run well, because there is no doing dissemination to all members of the police office of Senapelan. In practice there is still a member of the Police office of Senapelan who committed the violation of disciplinary violations and the duty defaulters Police Regulation No.14 of 2011 on the prohibition of the institutional ethics Article 13 paragraph 1 have mentioned that every member of the Police banned avoid or reject the official orders and paragraph 4 fellow member KEPP prohibited from KEPP breach of agreement or disciplinary or criminal offenses. In the implementation of sanctions against members of the police in the police office of Senapelan committing criminal offenses only did the Code without prior Assembly Session at the General Court. Whereas in Article 22 paragraph states the following sanctions decided by the trial PDTH recommendations KEPP after the first proven criminal offense through the judicial process general to a court decision which has permanent legal force.

Keywords: Law Enforcement, Code of Ethics.

\section{Introduction}

Law enforcement efforts undertaken by the government, can not be released from the police. Main Tasks Police itself according to Act No. 2 of 2002 on the police is to maintain security and public order, enforcing the law, and provide protection, shelter, and service to the community. ${ }^{2}$

Above objective is certainly not going to happen if not done with dedication, discipline and professionalism of the members of the Police itself to trying to perform the tasks assigned to them properly and responsibly. Based on the importance of discipline for members of the police as law enforcement, the government has issued regulations specifically governing the discipline of members of the police, the Government Regulation (PP) No. 2 of 2003 on the Members of the Police Disciplinary Regulations of the Republic of Indonesia. ${ }^{3}$

Police as a sub-system of the government is responsive has sought to contribute to realize the principles of Good Governance and Clean Government both in the

\footnotetext{
${ }^{1}$ Student of Masters (S2) of Law Faculty of Law Unissula and Police Officer of Purworejo email: Purwanto@gmail.com

${ }^{2}$ Article 13 of Act No. 2 of 2002 on the Law of the State Police of Replubik Indonesia.

${ }^{3}$ Ali Subur dkk 2007 Pergulatan Profesionalisme dan Watak Pretorian (Catatan Kontras Terhadap Kepolisian) Kontras p. 4
} 
implementation of the main tasks of maintaining internal security, enforcing the law and protecting, nurturing and serving the community or among the Polri itself as proclaimed in the grand strategy of the Police in the form of Trust Building. ${ }^{4}$ At least the statement further justifies that it is true in a lot of irregularities, especially the National Police in the Police professional code of ethics lapses. ${ }^{5}$

The code of ethics is a requirement, guidance or morals or decency guidelines for a particular profession or a list of obligations in running a profession which was prepared by the members of the profession itself and bind them in practice. Thus, the code of professional conduct containing ethical values defined as supervisor and controller suggestion how it should or should the holder of the profession act or behave or act in their profession.

Similarly, in the police profession, has a code of ethics for the police and the holder of policing functions. Code of conduct for the police profession is not only based on the needs of professionalism, but also has set normative in Act No. 2 of 2002 on the Indonesian National Police followed up with Government Regulation No. 2 of 2003 on the Police Disciplinary Regulations Member and Police Regulation No. Pol.: 14 of 2011 on the Code of Professional Ethics of Police and the Police Professional Code of Conduct So are binding for every member of the Indonesian National Police members. ${ }^{6}$ Police law enforcement personnel every certainly bound by the rules or the Act as a reference in the act. The rules that bind them are the National Police Act No. 2 of 2002 on the Police of the Czech Indonesi, Government Regulation No. 2 of 2003 on the Disciplinary Regulations Police officers and Police Regulation No. 14 of 2011 on the Code of Professional Ethics of Indonesian Police.

In the professional code of ethics penagakan Police in Police Purrworejo most have not been referred to the code of professional conduct KEPP. This happens because of violations committed by personnel still categorized as mild. But basically the enforcement of the code of ethics in Purworejo district police needs to be improved in order to run more leverage. Because it is an obligation for police officers at the police station and required Purworejo good cooperation among members of the police so that the Code can be run properly. But in practice, in the event of the customer code of ethics of Police.

\section{Research Methods}

The approach method or type of research used in the preparation of the writing of this study is to use a sociological juridical approach because it involves research that emphasizes the legislation or in the search for data that is used by adhering to the juridical aspect. In this method, the issues examined ranged in legislation, the legal relationship between the statutory regulations other legislation and its relation to the practice or application in society. However, the necessary data is not just hold of one

\footnotetext{
${ }^{4}$ Agus Dwiyanto 2006 Mewujudkan Good Governance Melayani Publik Yogyakarta; Gajah Mada University p. 3

${ }^{5}$ Ibid.

${ }^{6}$ Pudi Rahardi 2007 Hukum Kepolisian (Profesionalisme dan Reformasi Polri) Surabaya; Laksbang Mediatma p.6
} 
jurisdiction, but also pay attention to other terms, such as economic, social, cultural, and others.

The primary data obtained by jumping directly to the object of research to look at the state law enforcement KEPP in Purworejo district police. Secondary data obtained from studying books, literature, papers, and other materials relating to the writing of this study. Collecting data using observation, interview and literature study $\mathrm{dn}$ documentation. Presentation of data is done with the data that has been collected Data were analyzed using qualitative descriptive method where the discussion of research and the results are expressed through the words based on empirical data obtained. The data obtained in this study is qualitative data, because in this research using descriptive method and other materials relating to the writing of this study. Collecting data using observation, interview and literature study dn documentation.

Presentation of data is done with the data that has been collected data were analyzed using qualitative descriptive method where the discussion of research and the results are expressed through the words based on empirical data obtained. The data obtained in this study is qualitative data, because in this research using descriptive method and other materials relating to the writing of this study. Collecting data using observation, interview and literature study documentation. Presentation of data is done with the data that has been collected data were analyzed using qualitative descriptive method where the discussion of research and the results are expressed through the words based on empirical data obtained. The data obtained in this study is qualitative data, because in this research using descriptive method Presentation of data is done with the data that has been collected data were analyzed using qualitative descriptive method where the discussion of research and the results are expressed through the words based on empirical data obtained. The data obtained in this study is qualitative data, because in this research using descriptive method Presentation of data is done with the data that has been collected data were analyzed using qualitative descriptive method where the discussion of research and the results are expressed through the words based on empirical data obtained. The data obtained in this study is qualitative data, because in this research using descriptive method

\section{Results and Discussion}

\subsection{Kapolri of Implementation Regulation No. 11 of 2011}

Implementation of the code of ethics of Police supervised by Porvos Unit which is under the supervision element Chief of Police. This unit is in charge of implementing the coaching discipline, the maintenance of order, including internal security, in the context of discipline and code of professional conduct and service of the National Police public complaints about deviant behavior and actions of police personnel.

The function of the Police Code of Conduct for members of the Police Purworejo in institutional ethics is that tercipatanya discipline for members in charge, maintain and increase the image, solidarity, credibility, reputation and to avoid occurrence of interference by other parties while on duty as means of social control. In social ethics in order to provide the public with quick, precise, easy, convenient, transparent and 
accountable, uphold the truth, honesty, justice and safeguard the honor society. In the ethics of personality in order to train members of the national police in Purworejo district police be honest, trustworthy, responsible, disciplined, working together, fair, caring, responsive, and firm, so that can also be applied in family life, community and nation. In the ethics of state in order to maintain internal security, which includes maintenance of public order and safety From interviews conducted by the author at the Police Purworejo get that in the police station Purworejo there are violations committed by members of the police Purworejo form of discipline violation, absent duty, breach of discipline in the intent in the form of apples late morning, late for picket duty and late post custody. Police Police members Purworejo with disciplinary offenses were 9 people, breach of duty defaulters of 4 people and a violation of the use of narcotics group I defaulter duty, breach of discipline in the form of late apple intention morning, late for picket duty and late post custody. Police members Purworejo with disciplinary offenses were 9 people, breach of duty defaulters of 4 people and a violation of the use of narcotics group I defaulter duty, breach of discipline in the form of late apple intention morning, late for picket duty and late post custody. Police Police members Purworejo with disciplinary offenses were 9 people, breach of duty defaulters of 4 people and a violation of the use of narcotics group I as much as $2 p$

If the cumulative violations between disciplinary offense with the Code of Professional Ethics, the settlement is done through discipline or the Code of Conduct hearing Tops Ankum Police discretion of the examinee and opinions as well as legal advice and Bearer Function Legal Development. A policeman who violates the Code will be heard through the Police Ethics Commission hearing as elaborated in Article 19 paragraph 1 Police professional code of ethics.

Can be explained that according to article 19, paragraph 1, letter $b$, Commission Meeting Code of Police can also be done in case of violation be committing a criminal offense by oath, leaving the task or anything else and has been sentenced to discipline more than three (3) times.

From interviews conducted by the author at the Police Purworejo obtain that from members who commit disciplinary offenses, absent assignment and use of narcotics group I were in session at the Commission Code of Conduct is only a criminal offense of narcotics group I while breaches of discipline and loss to follow tasks are not heard by the Assembly Commission's Code ethics.

Sessions of the Commission Code of Conduct against members of the police who committed the crime can be implemented if there has been a decision of the general court who already have permanent legal force, because if the Commission Code of Conduct be implemented prior to the hearing in public courts, the decision of the Commission Code of Conduct will become disabled.

Its foundation is mentioned in article 12 paragraph 1 letter a PP No.1 of 2003 that a police officer who committed the crime can be dishonorably discharged through the decision of the Commission Code of Conduct if it has been declared subject to imprisonment by a court decision which has had permanent legal force, it is clear if the Commission's decision of the Code of Professional Police carried out against sanctions 
which heaviest namely PTDH (Dismissal With regards), but in fact at the hearing the general judicial police members is actually sentenced acquittal for not guilty of committing a crime, the Commission Code of conduct which has been carried out beforehand had been dropped a decision in the absence of evidence strong is the verdict of courts of general jurisdiction.

So it can be said that the session of the Police Professional Code of Conduct Commission carried out first before the general legal proceedings against members of the police who can commit criminal acts will not show the values of justice.

\subsection{Obstacles shape}

In practice not every police ethics code to be run well by every member of the police force. Many of them do violations of the code of conduct. Code violations is a mismatch every work of members of the police against the norms or rules that constitute ethical or philosophical foundation of the unity of the rules of conduct and sayings about things that are required, prohibited or not to be done by members of the police. In enforcing this Code in Purworejo district police does not constitute a major challenge for members, because it is an obligation for police officers at the police station and required Purworejo good cooperation among members of the police so that the Code could as well.

But the authors look at the practice field is also a violation of the Code in Purworejo district police, if it does not pose a significant challenge should be no violations of the Code of Conduct contained in the Police Purworejo.

Based on the results of interviews conducted by the author in Purworejo district police found that the obstacles in the implementation of rules Police Chief (Kapolri) in Purworejo is a fellow member there is mutual protection and whitewash a friend who commits an offense as well as the lack of well-being of members who became one of the obstacles implementing regulation Police Chief

From the above data it can be seen that seven respondents $(90 \%)$ has committed breaches of Purworejo KEPP at the police station, and 1 respondent (10\%) never violated KEPP. Respondents who have committed violations in Purworejo district police received a penalty in the form of Warning 2 respondent, the respondent and Sanctions Reprimand 13 respondents. Based on the above data it can be seen that always happens offenders KEPP in Purworejo district police. KEPP supposed violations should be avoided in order to create a good performance among members of the police.

\subsection{Completion}

Basically every member of the Police in Indonesia has often do KEPP offenses, both also committed by his subordinates as well as those made by his superiors. Many ways are done by the police officials to prevent violations KEPP, but still there is a violation KEPP. Instead of year-over-year increased KEPP violations.

Police Purworejo in an effort to prevent violations of the Code of Professional Ethics of Police, units Provos Police Purworejo perform actions such as give strict punishment to 
violators of the Code of Professional Ethics of Police so that offenders do not repeat the same action, remembrance and also provide guidance to all members of the police Purworejo done On Any Morning parade. Given decisive action aimed to provide a deterrent effect to members who have committed violations, from the data I get that a member who has committed an offense no repeat pelanggaranya.

Based on the results of interviews conducted by the author at the Police Purworejo get that there be disseminated Police Regulation to all members of the police Purworejo, should the police chief and Ka Provost conduct socialization to all members of the police Purworejo so that members of the police Purworejo understand and know the contents of the Police Regulation which aims to avoid violations committed by members of the police Purworejo. As well as in the improvement of the performance of members of the police professional Purworejo did increase prosperity to all members of the police Purworejo because of the results of interviews conducted by the author that the welfare of members in Purworejo district police is limited.

Although preventive measures to avoid violations Police KEPP in Purworejo, the fact that the author field could still there KEPP violations committed by police officers in the Police Purworejo. It seems there is no effect on the ever prevalent abuse or new offenses. Actions taken against violators KEPP be criminal in Purworejo district police is evidence of the inspection if deemed incomplete by the authority of the Provost Unit investigation by experts drawn Panimal Unit.

The investigation process is not only Paminal Unit which conducted an investigation, but also the Criminal Investigation Unit. Criminal Investigation Unit conducted an investigation only to find and collect evidence relating to such offenses. Evidence obtained by Paminal and Criminal has earned a strong allegations of violations of the code of conduct and criminal activity, then the next unit Paminal to report to the Unit Provost for then during the interrogation of any violations of the code of ethics and Unit Criminal resume in the investigation process the offenses that have taken place in accordance with pre-arranged in the criminal Code. Investigations conducted by the Provos actually been proven that there is a violation of ethics,

An act done by a policeman said as violations of the code of conduct, where members of the National Police has done not as stipulated in the regulations of the Police Professional Code of Conduct. In Police Professional Code of Conduct set rnengenai the existence of a moral consciousness of the conscience of every member of the Police so that every member of the police who have to sort out policing as a profession, with a sense of radar and responsibly carry out its obligations in accordance with the rules or norms that bind him.

\section{Closing}

\subsection{Conclution}

- Implementation of Police Regulation No.14 of 2011 on the Code of Conduct of Police at Police Resort Purworejo not run in accordance with the provisions stipulated in the Police Regulation No.14 of 2011, at the police station Purworejo in 
practice they are contrary to the content of Police Regulation namely Article 21 paragraph 3 and the trial process.

- Forms of violations and sanctions in the implementation of the Chief of Police perturan No.14 of 2016. In Purworejo violation Polrtes an increase from 2017. In the 2017 case of a breach of discipline 9, and defaulters task 4. Sanctions reprimand given to defaulters breach of duty, the physical sanction given to the offender.

- Completion of violations of rules Kapolri No.14 of 2011. In Purworejo district police to prevent violations KEPP Provost Unit provides strict sanctions. In Provost in fringement settlement unit was not working alone, Paminal Unit and Criminal Unit also help supplement the tools necessary evidence Provost Unit.

- Some overlap the implementation of Act No. 2 of 2002 and the Police Regulation No.14 of 2011 on the Police Code of Conduct as a reference for the investigation violation members of the police code of ethics when the violation follow two rules set out in the abovementioned.

\subsection{Suggestion}

- Provos unit should carry out supervision of Polres Purworejo members and also provide understanding to the contents of Act No. 2 of 2002 and the Regulation No.14 of 2011.

- Penalties are given to offenders should be firm, and the Police code of conduct commission must take a decision after the trial who already have permanent legal force. The Commission intended that the Code can take the right decision.

- In the prosecution of offenders must be according to the procedure, and the provost also have to investigate the truth.

\section{References}

[1] Achmad Ali 2002 Menguak Tabir Hukum (Suatu Kajian Filosofis dan Sosiologis Penerbit Toko Gunung Agung Jakarta

[2] Act 2 of 2002 on the Law of the Indonesian National Police.

[3] Agus Dwiyanto 2006 Mewujudkan Good Governance Melayani Publik Gajah Mada niversity Yogyakarta

[4] Ali Subur Dkk 2007 Pergaulan Profesionalisme dan watak Pretorian (catatan kontras pada kepolisian Kontras.

[5] Bambang Sunggono Metodelogi Penelitian Hukum. Rajawali Pers Jakarta

[6] Bartens 1994 Etika Gramedia Pustaka Utama Jakarta.

[7] Bersih dan Bertanggung Jawab Jurnal Pro Justisia Edisi IV (Bandung Universitas Parahyangan 2000)

[8] Dominikus Rato 2010 Filsafat Hukum Mencari: Memahami dan Memahami Hukum Laksbang Pressindo Yogyakarta

[9] Dwika "Keadilan dari Dimensi Sistem Hukum" http://hukum.kompasiana.com. (02/04/2011) .

[10] F.A.M. Stroink dalam Abdul Rasyid Thalib 2006 Wewenang Mahkamah Konstitusi dan Aplikasinya dalam Sistem Ketatanegaraan Republik Indonesia Bandung: Citra Aditya Bakti 
[11] Fajar Mukti Dualisme 2009 Penelitian Hukum Normatife dan Empiris Pustaka Pelajar Yogyakarta.

[12] Gunawan Setiardja 1990 Dialektika Hukum dan Moral dalam Pembangunan Masyarakat Indonesia Yogyakarta: Kanisius

[13] Perkap Polri No.14 of 2011 on the Code of Police

[14] PPRI No. 2 of 2003 on Members Police Discipline Regulations

[15] Pudi Rahardi 2007 Hukum Kepolisian (Profesionalisme dan Reformasi Polri) Laksbang Mediatma Surabaya.

[16] Sadjijono 2008 Etika Hukum Laksilang Medialanta Yogyakarta.

[17] Warsito Hadi Utomo 2005 Hukum Kepolisian di Indonesia. Prestasi Pustaka Publisher Jakarta

[18] Yan Pramadya Puspa 1987 Kamus Hukum Aneka Ilmu Semarang. 